\title{
Logistical Market Opportunities for Roasted Peanut Exports. A Case Study
}

\author{
Tomas Agustín BAS* \\ Researcher in International Trade and Technology Prospecting Universidad Catolica del Norte. 1281, \\ Larrondo, Zip Code 1780000, Coquimbo, Chile
}

*Corresponding Author: Tomas Agustín BAS, Researcher in International Trade and Technology Prospecting Universidad Catolica del Norte. 1281, Larrondo, Zip Code 1780000, Coquimbo, Chile

\begin{abstract}
The province of Córdoba, Argentine, is historically one of the largest producers and exporters of the oilseed Arachis hypogaea (peanut) worldwide. This, due to favorable soil conditions and optimal weather conditions of the province.

Therefore, the study was focused on a leading peanut producer company located in the Province of Córdoba for a research of the sector and a macro-research for the production and potentials for exportation of this productin Cordoba, Argentina.

A diagnosis was developed to understand the reality of the company in that specific moment after having made the situation analysis. Finally, an studyof the oilseed markets in Latin America was carried out, which led to the selection of Chile as the country that presented the greatest advantages when it came to entering into a viable logistical export potential for the company, entering the market through four variables of the "Marketing Mix".
\end{abstract}

Keywords: peanuts; roasting; Córdoba-Argentina; Chile; export logistics.

\section{INTRODUCTION}

The article analyzes a case study of an important peanut producing company in the Province of Córdoba, Argentina, with the intention of exploring and characterizing new target export markets within Latin America. The intention is to determine the logistic viability of the company to export the oilseed Arachis hypogaea, commonly known as "Peanut". Peanuts were selected as a star product because of the high demand for them and because of the innumerable benefits and properties they have for human consumption, since they are rich in proteins, oils, fiber, vitamins and carbohydrates (Zapata et al., 2012; Shi et al, 2016; 2017; Di Stasio et al., 2020; Bonku and Yu, 2020). Specifically, peanuts, in their roasted version, are a lower fat product than fried peanuts and are highly appreciated in the world as a snack (Kong et al., 2013; Guo et al., 2020). Additionally, it is important to highlight that the province of Córdoba (Argentina) contributes between 80 and $90 \%$ to the national production of this oilseed, while it stands out among the five largest world producers (Ackerman, 2006; Calzada and Rosadilla, 2018; Magyp, 2020). From the perspective of international trade, peanuts are in the chapter belonging to nuts or dried fruits (Jovtis and Juez, 2014). All these elements combined make the decision to analyze the market of the mentioned product in the time frame of the last years, with a strong emphasis on the complete statistical data of the years 2018 and 2019 for the industry.

\subsection{Scenario Analysis}

The company selected for the investigation of the case study and that we will call fictitiously "Maní S.A." to protect its anonymity, was founded in 2004 by four partners, in the area of the department Tercero Arriba, Province of Córdoba, Argentine Republic, where its agricultural exploitation is located, which has an area of 552 hectares. The society carries out the primary agricultural activity on its own fields and those of third parties on lease, seeking the highest sustainability and profitability both economically and agronomically, having in mind a permanent and constant growth in time.

The organization of the company is simple and has the four partners mentioned above as general managers, an external advisor in his capacity as an agronomist, who is in charge of the care and maintenance of the production of the fields and the personnel of sowing, spraying, fertilizing, 
fumigation and harvesting. In general, these last ones are outsourced services in charge of companies in the area dedicated to this field, since the company itself does not have machinery for such purposes.

The production of the crops is destined to both international and national markets, selling its production to companies in the area for further processing, the final destination of the goods being the foreign market.

The main investments that the company has are its own storage in a silo plant with capacity for 1500 tons of storage, weighing trucks, warehouses to store various machinery, seeds and agrochemicals.

The logistics of transporting the different inputs to the different production fields is carried out by means of specially hired trucks, since the company does not have its own vehicles. These inputs are stored in the supplier company. Herbicide and fungicide applications are also carried out by contractor companies (Universidad Siglo 21, 2020).

Through this project, it is sought to determine if the company "Peanuts S.A." has the logistic capacity to export its production by its own means, adding value to the company, since, as mentioned above, the entire harvest is sold to intermediary companies in the area, which in turn process and export the final product.

The value chain of the peanut production process begins with "arrancado" (as the peanut harvest is known, since the fruit is underground), which is carried out when it reaches values of between 15 and 22\% humidity (Pedelini, 2014; Bibbo et al., 2018; Calzada and Rosadilla, 2018; MAGyP, 2019). Once the peanuts are dry, they can be conditioned and sold raw as seed or for processing. It can then be roasted, which gives it a primary added value, and then conditioned and stored for later commercialization to the local or export market. This requires an initial investment in technology, both for harvesting, drying and roasting, or an outsourcing of this process. The first option can allow the company "Maní S.A." to commercialize this product directly to international markets, avoiding intermediaries and obtaining, at the same time, a greater economic profitability. In order to understand the complexity of the peanut logistic value chain, in figure 1 it is appreciated from the phase of inputs, materials knowledge, passing by the primary production, until the final consumption.

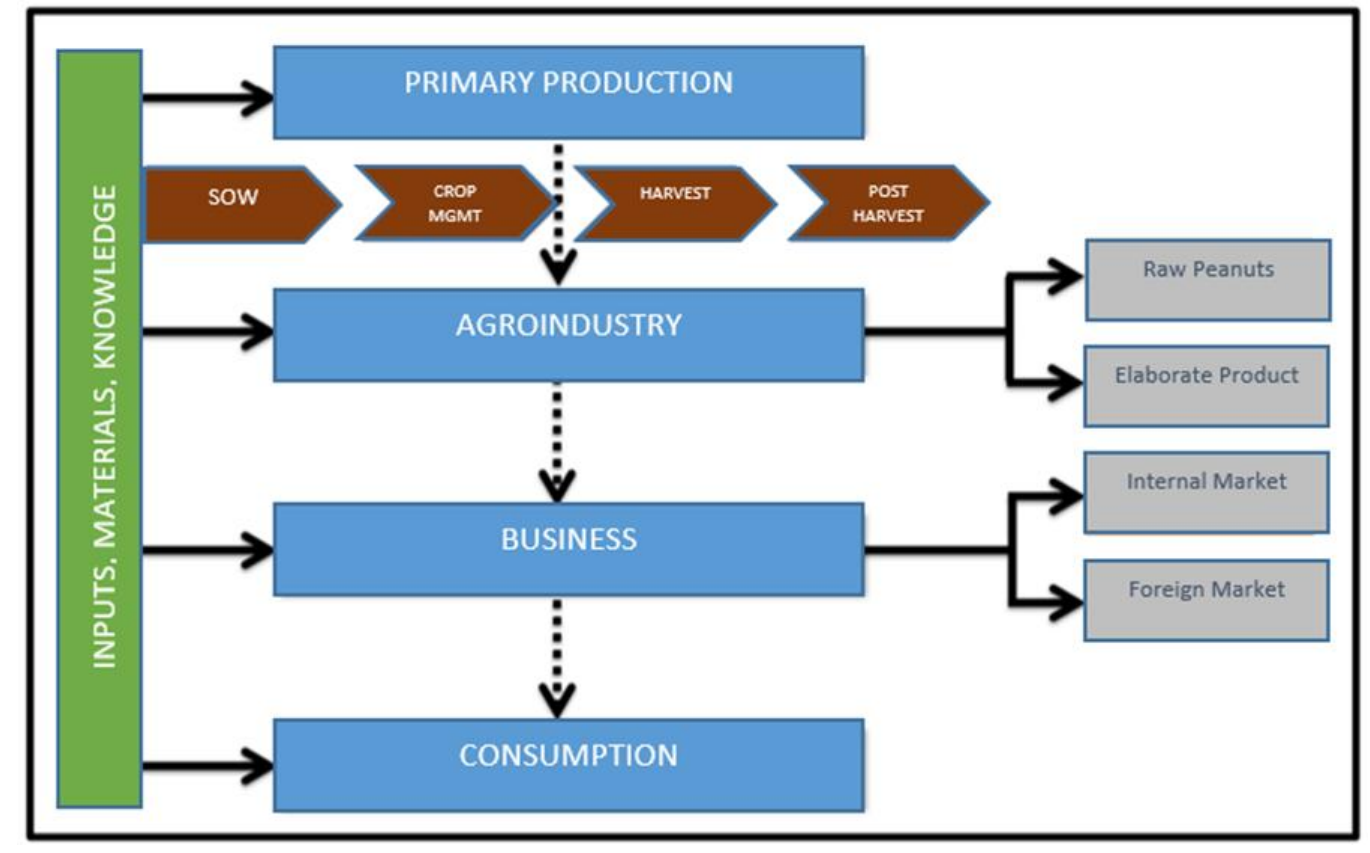

Figure1. Peanut Logistic Value Chain

Source: Bibbo et al., 2018

Taking into account the peanut logistic value chain, the article is organized as follows. First, the "roasted peanut" is analyzed, its characteristics and tariff position at the time of the study and its different interventions, considering the macro situation of its production through a PESTEL analysis with its corresponding factors and indicators. Then, an analysis of the internal sector of peanuts in general is made, to finally conclude with the world imports and exports of the product, which allows establishing the real and concrete possibilities of export and profitability of the company "Peanut S.A.". 


\subsection{Analysis of the Peanut Sector in Argentina}

With respect to the technological/eco-sustainable factor, there are numerous advances applied to peanut cultivation that have been generating improvements in both quality and productivity. These advances are in part the genetic jump, incorporating high oleic varieties (Bonku and $\mathrm{Yu}, 2020$ ); direct sowing, where at present almost $80 \%$ of peanuts are sown in this way, without tilling the soil; the practice of professional seed treatment, where the kilos per hectare have been considerably reduced; harvest logistics, where there is machinery to cover the existing demand (Calzada and Rozadilla, 2018). However, it is important to consider the drying machines, which are those used to remove excess moisture from peanuts; all this, in order to generate a decrease in production costs, with processes much more effective than in the past. Soil requirements for peanut cultivation are not very demanding in terms of nutrients, since they are usually sandy, not loamy clay, although at the same time they must be sufficiently aerated and loose (Pedelini, 2014).

It should be noted that, in order to sustain the various advances in the cultivation and high-yield harvesting of peanuts, in 2016 the Argentine Scientific and Technological Peanut Center was created in Córdoba, an institution that promotes research, development and innovation initiatives for the continuous improvement and support of peanut producers. On the other hand, the Ministry of Science, Technology and Productive Innovation, provides guidance and advice on funding tools for activities involving technological modernization (MCTeIP, 2020).

The constant advances in genetics play a fundamental role in achieving better yields, resistance and tolerance to different fungal, veronic and bacterial diseases that, in part, is what most affects peanuts and their proper development. Other key elements are given by the hydric stress, the cycle of the cultivation, the satisfaction of the different needs of the industry, as the form and size of the grain, organoleptic characteristics, among others (Pedelini, 2014).

\subsection{Peanut Production in the Province of Córdoba}

Historically, Córdoba leads the national production of peanuts with approximately $95 \%$ of what is cultivated (Calzada y Rosadilla, 2018), while a similar percentage of the national total is destined for export (Mich, 2019). Some 12,000 jobs are involved in the entire peanut agrifood chain (Revista Chacra, 2019). In recent years, this province has become the world's leading exporter, although with different nuances, as in 2018, where the political/financial situation, both local and international, coupled with the fall in commodity and grain prices, plus the severe drought at harvest time, caused major ups and downs throughout the production chain (Bibbo, et al., 2018). Even with all the circumstances listed, Córdoba continues to be one of the largest international suppliers of peanuts, ranking below China in terms of processed or preserved peanuts (Bibbo, et al., 2018; Calzada and Rosadilla, 2018; MAGyP, 2020). Although this province is currently ranked seventh in the world as a peanut producer, its domestic consumption is almost zero, reaching only $3 \%$ or 200 grams/inhabitant/year, compared to China, whose domestic consumption reaches $42 \%$ (https://www.peanutsusa.com/about-apc/the-peanut-industry.html).

However, this fact provokes an increase in the available volumes and makes possible the liberation of almost the totality of the production for its later exportation. Beyond this situation, it should be noted that, currently, the Argentine Peanut Chamber (CAM) is promoting a campaign to significantly increase the consumption of peanuts in the country. The agribusiness has, in the industrial link, a strong generator of added value, such as peanut oil, peanut paste, roasted peanuts, fried peanuts (Akhtar et al., 2014; Launio, 2018; Bonku and Yu, 2020). In this sense, and as far as peanuts with added value are concerned, Argentina leads the ranking of exports. In this sense, the BCR (2020) estimates that Cordoba is recognized in the world for the quality of its peanuts, as well as for the technological development it has achieved and which is seen in the excellence of its production, industrialization and conditioning for export. The peanut food chain represents a key piece in the country's productive matrix, occupying the top positions in the export ranking. (BCR, 2020, https://bit.ly/2VCa9Y2).

The Argentine Peanut Chamber or CAM (2020) estimates that $91 \%$ of Argentine peanuts are planted in the province of Córdoba, with an average of 350,000 hectares planted annually in 34 locations in Córdoba. However, due to the emergence of different problems related to crop diseases and the need to enrich the soil, producers can only plant the same lot with peanuts every four or five seasons, so it is imperative to rotate, if the resource is to be protected in the medium and long term. 
The existence of an "Argentine Peanut Cluster" allows primary producers to be integrated with industry and exports, forming part of a chain with very good synergy (Bibbo, et al., 2018). In the Cluster, the peanut growers are associated in cooperatives which, in turn, have their own industrial plants and export operations, or maintain associative agreements with the industrial companies. In addition, they implement and certify different quality standards, such as good manufacturing practices, HACCP, ISO, GFS, among others (CAM, 2017).

In addition to the above, Fundación Maní Argentino was created in 2001 with the aim of promoting the development and improvement of the activity through the encouragement, promotion of research, dissemination of techniques, the sustainability of the crop and the preservation of the ecosystem (Fundación Maní Argentino, 2020).

The denomination "MANÍ DE CÓRDOBA - Certification of Origin" is a quality seal launched in 2007 to the international market, by the Argentine Peanut Chamber (CAM, 2020) guaranteeing a Premium quality, according to the most rigorous international standards. Its attributes make "MANÍ DE CÓRDOBA" an extremely attractive product for consumers, with high quality and superlative nutritional values. This denomination offers guarantees of a product free of chemical and biological contaminants, cultivated under assurance standards, while it has a specific nutritional composition inherent to its geographical origin. This appellation is distinguished when it comes to roasted peanuts, by a flavor with sweet reminiscence, thanks to the important content of sucrose, characteristic of the peanuts planted in these latitudes.

\subsection{International Peanut Analysis.}

Argentina stands out worldwide for the quality of its peanuts. As shown in figure 2, more than 341,800 hectares of land have been allocated for a production of almost 3,000 kg/ha. Calzaada and Rozadilla (2018), explain that $50 \%$ of peanut exports are made by only four large companies, $39 \%$ is made by nine medium sized companies and the remaining $11 \%$ is made by 11 small companies. According to data from INDEC (2020), exports from the peanut exporting complex, in 2018, reached a value of 717 million dollars, of which almost 458 million dollars are from the tariff position studied.

Due to the scarcity of available literature providing reliable and current data, we will be guided by those provided by Trade Map (2020), which suggests that Argentina, in 2018, contributed almost 20\% of the world's exports of processed or preserved peanuts, in reference to the value exported, but below China, which obtained about $27 \%$ of the total share. Argentina's trade balance is extremely positive, since practically everything produced is exported, due to the fact that, as already mentioned, domestic consumption is very low. It should be clarified that, although Argentine peanuts have very good genetic, phenotypical and organoleptic characteristics, among the top 25 exporters, Argentina has the lowest unit value per ton, so it depends heavily on market fluctuations, so if its price were higher per ton, it should obtain an even more positive trade balance. A negative point is the average geographical distances of the importing countries, Argentina doubles and even triples these distances, with the consequent logistic damage. A particular fact is that, of the total quota exported, China and Argentina take 59.36\%. In this sense, we observe that the Netherlands and the United States concentrate, between the two, only $16.5 \%$ of exports, but in terms of world shares they participate with $21.2 \%$. This is due to its high unit value per ton, where the average is USD 2600, compared to USD 1900 for China and USD 1390 for Argentina (MAGyP, 2019).

With regard to imports of this product for 2018, we find the United States in first place with 151,189 million dollars and within the top 8 of the main importers. It is the only country with a positive trade balance, while there are countries with a significant negative trade balance, such as France and Japan. The top 8 importers cover almost $50 \%$ of world imports of this product.

Argentina exports this oilseed mainly to the Netherlands, with a share of Argentine exports for this position of almost $30 \%$. Within the top 10 of the main importers, nine are European and one South American, which is Chile, being in the ninth position with a value of about 20 million dollars and a share of Argentine exports of $4.5 \%$ for this position. Other Latin American countries that emerge are Uruguay and Colombia, but behind the 20th position and with less than $1 \%$ in representation of exports. The unit values per ton in dollars are quite similar, except for the United States, where their value increases by $50 \%$ (Trade Map, 2020). 


\subsection{Logistical Analysis of the Macro Export Scenario}

We begin by presenting the tariff classification for the peanut product to be analyzed in the Argentine Republic:

Section: IV. Products of the food industries; beverages, alcoholic liquids and vinegar; tobacco and substitutes.

Chapter: 20. Preparations of vegetables, fruits or other parts of plants.

Heading: 2008. Fruit, nuts and other edible parts of plants, otherwise prepared or preserved, whether or not containing added sugar or other sweetening matter or spirit, not elsewhere specified or included.

Subheading: 2008.11. Peanuts.

The NCM tariff position: 2008.11.00 - Peanuts (peanuts, groundnuts)*.

The SIM tariff position is: 2008.11.00 390 M - Roasted - Other.

For this tariff position, there is a $9 \%$ export duty with a maximum ceiling of $\$ 3$ per US dollar of dutiable value or FOB price and a 1.25\% refund applicable to exports to Intra- or Extra-zone. Within the special treatments, there is an additional $0.5 \%$ refund for products that have the condition of organic, biological or organic duly certified and authorized by the competent body; products with the right to use the "Argentine Food Seal a Natural Choice" and, finally, products that have a "Designation of Origin" or a "Geographical Indication". Finally, there is a reduction in export duties payable by Micro, Small and Medium-sized Enterprises (MSMEs).

On the other hand, for special cases in triangulation operations, an advance income tax of $0.50 \%$ is paid for each export operation (Chile is a cooperating country for fiscal transparency purposes). With respect to the exchange market, the term to enter and liquidate the foreign currency in the local market has to be within five (5) working days from the date of collection of the export.

As prior interventions, for the purpose of exporting the food product, which is the responsibility of the National Food Institute (INAL), exporters must make an Export Notification by completing the corresponding Form. It is discarded as a previous intervention to SENASA because it is a product for human consumption (TARIFAR, 2020).

A PESTEL analysis is carried out to know the general environment affecting the companies and their situation. Aguilar (1967) coined this tool used in strategic management, which takes into account the following factors: Political, Economic, Social, Technological, Ecological and Legal. For this, the different factors are identified starting with the economic one since it is understood that it is the most important and with the greatest incidence. The indicators used are: exchange rate, consumer price index (CPI), GDP per capita, the trade balance and country risk. Some of these are hybrid indicators since in addition to being included in the macro analysis they are also part of international analysis, so they are the last to be analyzed.

When trading internationally, the exchange rate of our country must be taken into account since it is a key factor for any company that wants to enter international markets.

The exchange rate between pesos and dollars, as of 02/28/2020 (when the study was made), is $\$ 62.21$ per dollar, which is extremely fluctuating due to the situation in Argentina and now with the Covid-19 pandemic affecting the world in 2020. This analysis shows that the greatest variations are positive in terms of the depreciation of the peso with respect to the dollar and, therefore, it is expected that the dollar will continue to appreciate. The greatest variations have been in the months of August, both for 2018 and 2019, with values around 35\% higher than the previous months. In January 2020, for the first time, the barrier of $\$ 60$ per dollar was exceeded. This high exchange rate, to some extent, favors exporting companies.

The variation of prices of goods traded in the domestic market is a determining factor to be taken into account by companies operating in the same. On the other hand, excessive increases in the cost of inputs must be addressed in order to adjust the sales prices of products, maintaining a margin of profitability that allows the company to preserve good financial conditions.

With respect to the percentage of variation, according to data from the INDEC (2020), we have observed how since 2018 the percentage of variation in consumer prices has been fluctuating, with peaks in September and October 2018 and lows in July 2019 and January 2020. 
According to data from SantanderTrade (2020), it is analyzed that Argentina's GDP per capita from 2003 to 2012 registered an expansion at relatively high levels due to the rise and "explosion" of raw material prices, but after several erratic political decisions, such as exchange controls or heavy indebtedness, it was followed by a stagnation from 2012 that lasts until today. The country would even experience two years of consecutive decline, something that has not happened since 2002. By 2019 , the country is in the sixth position of GDP per capita in Latin America, with a value of USD 9,933 and it is expected that this amount will continue to fall in the coming years.

In the trade balance, also called Argentine trade exchange (ICA), exports and imports are analyzed with their respective dollar balances. Based on this, our own analysis based on INDEC data (2020) shows that Argentina went from having a deficit of more than three billion dollars in 2018 to having a surplus of almost sixteen billion dollars in 2019.

This is due to a very large reduction in imports in 2019 compared to 2018 due to the rise in the real exchange rate and also to the contraction in national and international economic activity. In relation to exports, there is not a very marked variation, although a percentage of exports did rebound, having a positive result for the eleventh consecutive month. In relation to America we can see that it also went from a deficit trade balance to a surplus, with an amount of 3 billion USD.

The country risk is an indicator that shows how the situation of a country is through the interest surcharge paid by each country to finance itself in the international market. According to data collected from Ámbito (2020) the values of country risk since the beginning of 2019 have been averaging 800 points, obtaining a take-off in mid-August after the "PASO" elections and maintaining a constant above 1700, reaching a peak of 2532 points of country risk on August 30, 2019. This rise does not occur spontaneously, but rather is due to the lack of confidence of the markets in Argentina, in relation to the risks of not being able to meet their payment commitments. Due to the same risk situation, there is also no confidence to invest in the country, among others, because of the lack of competitiveness, a high tax rate and lack of legal security. The country will always be able to have external financing, which happens because of the high country risk, the interest rate that is achieved is also very high and the financing is very expensive and sometimes very unprofitable.

Within the political/legal factor of the PESTEL analysis, the trade agreements that Argentina has with the rest of the countries are considered, as well as the export promotion and encouragement agencies. Starting with the first point, it can be seen in Figure 2 that Argentina has 20 international trade agreements in force, which have been signed from 1990 to 2018. Of these agreements, 13 were signed through the MERCOSUR, six were reached bilaterally and one was the incorporation to the WTO. In July 2019 an extremely important agreement was signed between MERCOSUR and the European Union. We note that Argentina has not made bilateral agreements with countries outside Latin America, but all agreements with countries outside this territory have been through MERCOSUR. We also point out that the largest number of trade agreements were signed in years where the trade balance was more positive. It is important to add that Argentina is a member of ALADI (Latin American Integration Association), the largest Latin American integration group that exists today.

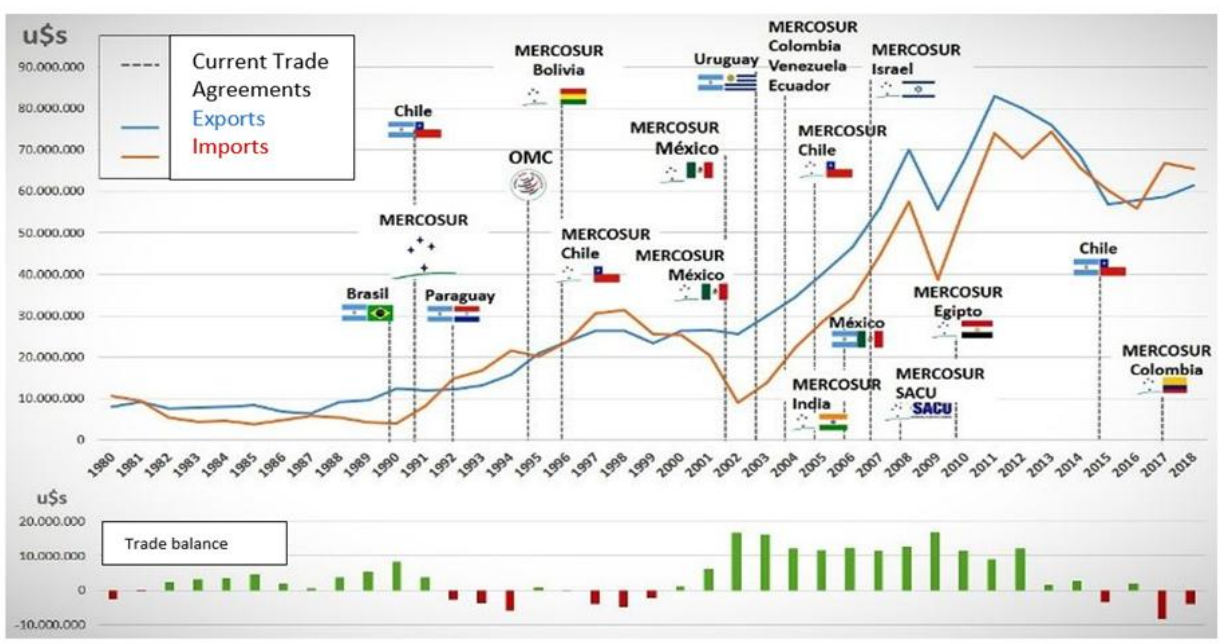

Figure2. Trade agreements in Mercosur

Source: El Cronista (2020, https://bit.ly/2klkHuI). 
Since we mention the export promotion and encouragement organizations that collaborate with companies, for the internationalization process, we have to mention the Argentine embassies in each destination country, as well as the CNCE (National Commission of Foreign Trade), Pro Argentina, the Argentine Agency for the Promotion of Investment and International Trade, the Pro Córdoba Agency, ExportAr, etc.

\section{MeThodology: MARKeT ReSEARCH}

Market research could be defined as the function that links a company with its own market, through the collection of information, which facilitates the identification, definition of market opportunities and problems, as well as the development and evaluation of marketing actions (Hair, et al., 2010), also allows monitoring market performance and improving the understanding of marketing as a business process (Tarka, 2019; Dichev, 2020).

To conduct quality market research or analysis, timely, accurate and relevant information on the structure of the international market at the global level is required. A key tool is statistical data, which makes it possible to: a) analyze trade statistics on exports and imports, b) study price indexes, taxes payable and non-tariff barriers, c) recognize trading partners, d) identify marketing channels, d) define aspects related to logistics, etc. These data will allow the organization to identify the main participants in world trade of the product in question (Riesener et al., 2019).

Once the markets have been analyzed, a methodology is adopted for selecting the country that presents the best conditions for exporting the product.

This study uses the hierarchical analysis process tool (AHP, Analytic Hierarchical Process) or multicriteria decision rule developed by Saaty (1988) to facilitate decision making and that tries to satisfy as many of the established objectives as possible.

Multi-criteria analysis is used essentially for understanding and solving decision problems and makes it possible to make comparative judgments. It is characterized by the diversity of factors that are integrated into the evaluation process and its particularity lies in the way it transforms measurements and perceptions into a single scale, so that elements can be compared and priorities established.

Once the criteria are defined, they are weighted, assigning them a relative weight, which indicates the relative importance in the eyes of the researcher. It is often considered a scale of values between a range of 1 to 5 , where 1 represents the worst conditions and 5 the best conditions.

Finally, the tool of the "International Marketing Mix" was chosen, from its four variables (product, price, place and promotion) working together in all the actions that the company carries out, to influence the demand of its products, in order to achieve its commercial objectives. The four variables are set out below:

- Product: is the combination of goods and services that the company offers to the target market seeking to satisfy the needs of customers. The important aspects to work on this variable range from image, brand, to packaging or after sales service. Keegan (2000) highlights different strategies to adapt and/or expand the product and message to new markets:

- Direct extension: it is the simplest product strategy. The exact same product is sold, with the same advertising and promotions as used in the country of origin.

- Adaptation of the message: the product covers a different need and attracts a different segment, under conditions of use similar to those of the national market, the only adjustment is made to the message.

- Adaptation of the product: the message strategy of the source market is extended, but the product is adapted to the use or conditions of preference of consumers at the destination.

- Adaptation of the product and message: the conditions of use or preference differ greatly and both the product and the message itself need to be adapted.

- Product invention: planning and designing for the global market; developing a new product with its respective communication strategy.

- Price: it is the variable through which a company's income enters. The consumer will decide if we have set the price correctly, since he will compare the value received from the product purchased, against the price he has paid for it. 
Kotler and Keller (2017) establish three aspects to consider for the correct determination of a price strategy:

- Overall pricing strategy: in which competition and costs have influenced the pricing decision, competitive prices can be determined by examining the price levels of competitive and substitute products in the target markets.

- Strategies for export pricing: there are two main general alternatives, on the one hand to set a penetration price, where the product is offered at a low price, seeking to generate a good level of sales and broad market share, the other alternative is to skim the market, the objective of this is to obtain the best benefits in a short time, with this method the product has to be unique and customers must be willing to pay a high price.

- Pricing in international marketing: they are divided into three strategies such as: standard world price, double pricing, which differentiates export prices from domestic prices, and finally, pricing for the differentiated market.

Place or distribution: set of company activities that make the product available to consumers. This variable works on aspects such as storage, inventory management, transport, location of points of sale, order processes, etc. The channels through which the products can be sold can be physical points of sale, franchises, representatives, e-commerce platforms, online stores.

Promotion: international promotion strategies are the activities and tools used by companies to make their products known in foreign markets in order to increase sales. The most important tools are: international fairs, business rounds, commercial missions, promotional material and samples.

\section{Diagnosis of the Company "Peanut S.A."}

From what was investigated in the situation analysis, it is observed that, although the company "Peanut S.A." is not currently in a position to export, it does have opportunities to achieve an export of the product "roasted peanuts" in its own name and right. This situation is due to many reasons, such as the very good production of peanuts that the company has. On the other hand, it is possible to request the certificate of origin "Peanut from Cordoba" which gives added value, knowing that this product is highly appreciated and required by many countries, also the "CAM" offers reports and assistance to companies in this regard.

It is also known that the company does not have its own tools for all the peanut processing, but it is estimated that, by making an adequate investment in machinery for the collection and drying of the peanuts, as well as their cooking for roasting, "Maní S.A." can export its star product, with an added value to the different markets, thus putting its production directly on the shelves. The great advantage of this procedure is that it avoids having to outsource the processes, as well as the sale of the "raw" peanuts in their entirety to companies in the area for processing, as it does at present.

It is important to carry out the diagnosis for the company, to analyze the possibilities of obtaining greater economic benefits from its product. However, it is necessary to consider that the great devaluation of the peso with respect to the dollar leads to an increase in fixed costs, company inputs and logistic costs, it also presents an incentive for exportation, since the company's products will be able to be more competitive in international markets. The above is complemented by the different bilateral agreements that Argentina has, as well as its membership in MERCOSUR and ALADI, which is supported by the reduction of taxes (duties, refunds, etc.). Another interesting opportunity lies in the reduction of peanut withholdings, which go down from four to three pesos per exported dollar.

\subsection{Implementation Proposal}

The proposal is based on a market research gathering information, both from the preliminary international analysis made in this work, and also through a new study on Argentine exports of the product "roasted peanuts" and its tariff position (2008.11.00 390 M) to Latin American countries (Exporters of Córdoba (2020).

Argentina has a 19.3\% share in the world peanut export value, however in 2018 its figures were close to those of China with a $27.5 \%$ share, but as it has a unit value per ton well below the other countries, its share seems lower. This low unit value can be an advantage to sell the product to foreign markets at a lower price than other competing countries, also remembering that Argentine peanuts are recognized as one of the best peanuts worldwide, for their highly superior quality. 
Table 1 allows us to observe the exports from Argentina to Latin American countries, where Chile clearly stands out as the first commercial partner of Argentina in Latin America, with a participation of exports for our country of $4.5 \%$ and a value of 20.8 million dollars. Then, far behind are Uruguay with $1.1 \%$ of exports, Colombia with $0.6 \%$, Peru $0.2 \%$, Mexico $0.1 \%$ and already, in last place, Ecuador with negligible numbers.

Table1. Exports from Argentina to Latin American Countries

\begin{tabular}{|c|c|c|c|c|c|c|c|}
\hline Importers & $\begin{array}{l}\text { Value } \\
\text { exported } \\
\text { in } 2018 \\
\text { (thousand } \\
\text { of USD) } \\
\end{array}$ & \begin{tabular}{|c} 
Trade \\
balance in \\
2018 \\
(thousand \\
of USD)
\end{tabular} & $\begin{array}{c}\text { Share of } \\
\text { exports } \\
\text { for } \\
\text { Argentina } \\
(\%)\end{array}$ & $\begin{array}{c}\text { Quantity } \\
\text { exported } \\
\text { in } 2018\end{array}$ & $\begin{array}{l}\text { Unit value } \\
\text { (USD/unit) }\end{array}$ & $\begin{array}{c}\text { Share of } \\
\text { partners } \\
\text { countries in } \\
\text { world } \\
\text { imports }(\%)\end{array}$ & $\begin{array}{c}\text { Average } \\
\text { tariff } \\
\text { (estimated) } \\
\text { faced by } \\
\text { Argentina }\end{array}$ \\
\hline World & 457.694 & 457.369 & 100 & 328.835 & 1.392 & 100 & - \\
\hline Chile & 20.804 & 20.804 & 4,5 & 13.670 & 1.522 & 0,8 & 0 \\
\hline Uruguay & 4.913 & 4.913 & 1,1 & 2.592 & 1.895 & 0,4 & 0 \\
\hline Colombia & 2.623 & 2.623 & 0,6 & 1.861 & 1.409 & 0,3 & 0 \\
\hline Peru & 715 & 715 & 0,2 & 444 & 1.610 & 0,2 & 0 \\
\hline Mexico & 624 & 624 & 0,1 & 442 & 1.412 & 1,7 & 16 \\
\hline Ecuador & 119 & 119 & 0 & 85 & 1.400 & 0,1 & 0 \\
\hline
\end{tabular}

\section{Source: International Trade Center (2020, https://bit.ly/2BOEycH)}

With respect to Argentina's trade balance, which is equal to the difference between the value of exports and imports, it was almost identical to the value exported in 2018 and, therefore, positive, since, historically, what is produced tends to be exported almost in its entirety.

Analyzing the values paid by these countries (dollars per ton) in 2018, it is shown that Uruguay was the most expensive country to pay per ton in dollars, with a value of 1895 dollars, while Colombia, Mexico and Ecuador are around 1400 dollars, while Peru and Chile approximately 1610 and 1522 dollars respectively. Therefore, it can be seen that the value paid is higher than the approximate value Argentina usually sells per ton. This is mainly due to the fact that European countries sell the ton at a much lower price than Latin American countries, perhaps also due to the quantities they import and the importance of entering the European market.

If we add up all the Latin American markets, we do not reach the 7\% share of Argentine exports, which is a low value and this shows that the great majority of exports of Argentine origin, for this product, are directed to Europe. But that does not mean that there are few opportunities in Latin America, adding that the unit value paid is higher, and for the company and a first export as we have mentioned, the Latin American market is more accessible.

If we take ALADI as a peanut exporting group, it represents $22.3 \%$ of world exports. Argentina only has $19.3 \%$. The remaining $3 \%$ is monopolized by Mexico with $1.9 \%$ and Brazil with $0.9 \%$. This means that more than $86 \%$ of LAIA's exports of this product are made by Argentina. This shows that Argentina is a very strong country in terms of peanut exports, having practically no competitors in the area.

To start the tool (multi-criteria matrix), the countries were filtered and selected and then analyzed in the matrix, seeking to identify commercial opportunities for roasted peanuts in Latin America, so the rest of the world was discarded. MERCOSUR member countries and associated States were also investigated. Countries such as Brazil were eliminated because, although consumption of this product is high, its production is sufficient for self-supply and export only the surplus, added to its almost zero import of this product, with only 119 tons per year approximately. We are challenging Venezuela due to the critical political and economic situation. Ecuador was also left out of the analysis because its peanut imports are low and most of these few imports come from Brazil.

For the reasons mentioned above and adding up the negative trade balances and high consumption of Latin American countries with respect to the product, they passed the second filter: Chile, Colombia, Mexico, Peru and Uruguay. With the countries already defined, the variables in the matrix were 
developed to order and prioritize the potential export markets for the company. This tool made it possible to compare the countries based on important criteria, managing to order them in order to establish the most suitable market to go to.

The variables considered in the matrix were then identified by:

- Total imports of the tariff position (Table 2)

- Imports of Argentine peanuts compared with other countries (Table 3).

- Taxes to be paid (Table 4).

- GDP per Capita (Table 5).

- Distance to destination country (Table 6).

- Inflation rate (Table 7).

- Economic Freedom (Table 8).

Table2

\begin{tabular}{|l|c|c|c|}
\hline \multicolumn{4}{|c|}{ Tons imported from the position 20.08.11 } \\
\hline & Tons & Value & Range \\
\hline Chile & 15.927 & 5 & $6000=>$ more \\
\hline Colombia & 2.830 & 2 & $1500=>2999$ \\
\hline Mexico & 11.892 & 5 & $6000=>$ more \\
\hline Peru & 1.407 & 1 & $0=>1499$ \\
\hline Uruguay & 3.196 & 3 & $3000=>4499$ \\
\hline
\end{tabular}

\begin{tabular}{|c|c|}
\hline \multicolumn{2}{|c|}{ Value in Tons } \\
\hline 1 & $0=>1499$ \\
\hline 2 & $1500=>2999$ \\
\hline 3 & $3000=>4499$ \\
\hline 4 & $4500=>5999$ \\
\hline 5 & $6000=>$ more \\
\hline
\end{tabular}

Source: Own elaboration based on the International Trade Center (2020)

Table3

\begin{tabular}{|l|c|c|c|}
\hline \multicolumn{4}{|c|}{ Argentine peanut imports compared to other countries } \\
\hline & $\%$ & Value & Range \\
\hline Chile & 85,8 & 5 & $80=>$ more \\
\hline Colombia & 65,8 & 4 & $60=>79,9$ \\
\hline Mexico & 3,8 & 1 & $0=>19,9$ \\
\hline Peru & 3,2 & 1 & $0=>19,9$ \\
\hline Uruguay & 80,1 & 5 & $80=>$ more \\
\hline
\end{tabular}

\begin{tabular}{|c|c|}
\hline \multicolumn{2}{|c|}{ Values in percentages } \\
\hline 1 & $0=>19,9$ \\
\hline 2 & $20=>39,9$ \\
\hline 3 & $40=>59,9$ \\
\hline 4 & $60=>79,9$ \\
\hline 5 & $80=>$ more \\
\hline
\end{tabular}

Source: Own elaboration based on International Trade Center (2020)

Table4

\begin{tabular}{|l|c|c|c|}
\hline \multicolumn{4}{|c|}{ Taxes to pay } \\
\hline & $\%$ & Value & Range \\
\hline Chile & 0 & 5 & 0 \\
\hline Colombia & 0 & 5 & 0 \\
\hline Mexico & 16 & 1 & $10=>$ more \\
\hline Peru & 0 & 5 & 0 \\
\hline Uruguay & 3 & 3 & $3=>5,99$ \\
\hline
\end{tabular}

\begin{tabular}{|c|c|}
\hline \multicolumn{2}{|c|}{ Values in Percentages } \\
\hline 5 & 0 \\
\hline 4 & $0=>2,99$ \\
\hline 3 & $3=>5,99$ \\
\hline 2 & $6=>9,99$ \\
\hline 1 & $10=>$ more \\
\hline
\end{tabular}

Source: Own elaboration based on MREyC (2020)

Table5

\begin{tabular}{|l|c|c|c|}
\hline \multicolumn{5}{|c|}{ GDP per capita (2019) } \\
\hline & USD & Value & Range \\
\hline Chile & 16.272 & 5 & $10.000=>$ more \\
\hline Colombia & 7.049 & 3 & $5.000=>7.499$ \\
\hline Mexico & 9.866 & 4 & $7.500=>10.000$ \\
\hline Peru & 7.362 & 3 & $5.000=>7.499$ \\
\hline Uruguay & 17.875 & 5 & $10.000=>$ more \\
\hline
\end{tabular}

\begin{tabular}{|c|c|}
\hline \multicolumn{2}{|c|}{ Values in USD } \\
\hline 1 & $0=>2.499$ \\
\hline 2 & $2.500=>4.999$ \\
\hline 3 & $5.000=>7.499$ \\
\hline 4 & $7.500=>10.000$ \\
\hline 5 & $10.000=>$ more \\
\hline
\end{tabular}

Source: Own elaboration based on Santander Trade (2020)

International Journal of Managerial Studies and Research (IJMSR) 
Table6

\begin{tabular}{|l|c|c|c|}
\hline \multicolumn{4}{|c|}{ Distance to destination country } \\
\hline & Kilometres & Value & Range \\
\hline Chile & 648 & 5 & $0=>1.499$ \\
\hline Colombia & 4.141 & 3 & $3.000=>4499$ \\
\hline Mexico & 6.771 & 1 & $6.000=>$ more \\
\hline Peru & 2.524 & 4 & $1.500=>2999$ \\
\hline Uruguay & 839 & 5 & $0=>1.499$ \\
\hline
\end{tabular}

\begin{tabular}{|c|c|}
\hline \multicolumn{2}{|c|}{ Values in Kilometres } \\
\hline 5 & $0=>1.499$ \\
\hline 4 & $1.500=>2999$ \\
\hline 3 & $3.000=>4499$ \\
\hline 2 & $4.500=>5999$ \\
\hline 1 & $6.000=>$ more \\
\hline
\end{tabular}

Source: Own elaboration

Table7

\begin{tabular}{|l|c|c|c|}
\hline \multicolumn{5}{|c|}{ Rate of inflation (2018) } \\
\hline Chile & $\%$ & Value & Range \\
\hline Colombia & 2,43 & 4 & $1,50=>2,99$ \\
\hline Mexico & 3,24 & 3 & $3=>4,49$ \\
\hline Peru & 4,89 & 2 & $4,50=>5,99$ \\
\hline Uruguay & 7,31 & 5 & $0=>1,49$ \\
\hline
\end{tabular}

\begin{tabular}{|c|c|}
\hline \multicolumn{2}{|c|}{ Values in Percentages } \\
\hline 5 & $0=>1,49$ \\
\hline 4 & $1,50=>2,99$ \\
\hline 3 & $3=>4,49$ \\
\hline 2 & $4,50=>5,99$ \\
\hline 1 & $6=>$ more \\
\hline
\end{tabular}

Source: Own elaboration based on World Bank (2020)

Table8

\begin{tabular}{|l|c|c|c|}
\hline \multicolumn{4}{|c|}{ Economic freedom (2019) } \\
\hline & Position & Value & Range \\
\hline Chile & 18 & 4 & $15=>29$ \\
\hline Colombia & 49 & 2 & $45=>59$ \\
\hline Mexico & 66 & 1 & $60=>$ more \\
\hline Peru & 45 & 2 & $45=>59$ \\
\hline Uruguay & 40 & 3 & $30=>44$ \\
\hline
\end{tabular}

\begin{tabular}{|c|c|}
\hline \multicolumn{2}{|c|}{ Values } \\
\hline 5 & $0=>14$ \\
\hline 4 & $15=>29$ \\
\hline 3 & $30=>44$ \\
\hline 2 & $45=>59$ \\
\hline 1 & $60=>$ more \\
\hline
\end{tabular}

Source: Own elaboration based on The Heritage Foundation (2020)

In table 9, it can be seen that, by far, the best destination country is Chile, due to the great demand for the product studied, having been supplied mainly by the Argentine peanut. As far as could be observed, the Argentinean peanut was well valued and appealing within the trade. Also played in favor of bilateral agreements with the neighboring country, added to the fact that it is a country associated with MERCOSUR, and where taxes, also more affordable, have a positive influence. Its high GDP per capita for the region and its low inflation in the last years denote a "good" purchasing power for our product. As it is a bordering country and is located less than 1,000 km away from Cordoba, any inconvenience that may arise in a first export can be solved more easily than if it were some other country more distant geographically. The distance also makes it easier for Chilean buyers to visit the country, either by appearing in person with them or by visiting trade fairs at much more accessible global costs.

Table9. Multi-criteria Matrix

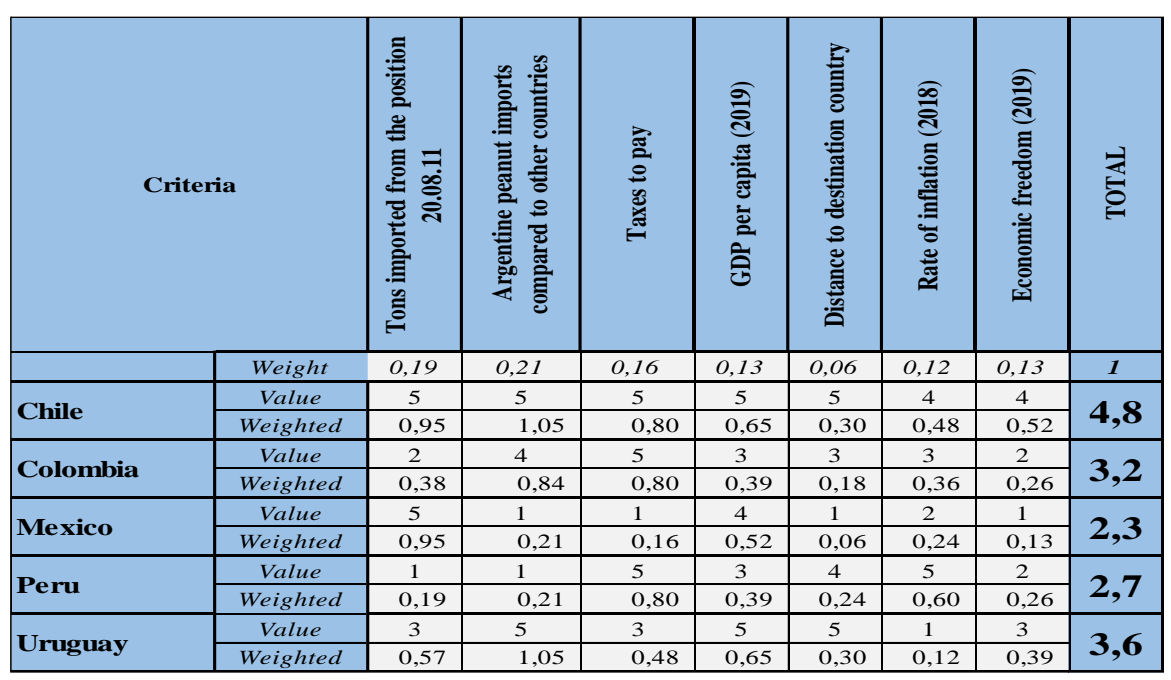

Source: Own Elaboration

International Journal of Managerial Studies and Research (IJMSR) 


\section{2. "International Marketing Mix" to Analyze Market Entry}

International marketing mix activities are often critical to the prosperity of many business organizations operating in today's globalized economy because of the number of uncontrollable variables they must consider in the countries where they operate (Akgün et al., 2014). In that sense, Falahat et al. (2020) consider four essential export capabilities (market intelligence, product innovation, pricing and marketing communication) as determinants of competitive advantage for exporting SMEs. Considering these circumstances, within the product strategies, the direct or "dual" extension was selected, since no changes are required in the product itself, nor in the way it is offered, understanding that future clients in Chile will use roasted peanuts in the same way as in Argentina. Also, given the condition that for "Maní S.A." was its first export, the direct extension can be functional since its costs are relatively low, besides being the most plausible and economic strategy.

In terms of packaging design and labeling, we sought to adapt the presentations to customer requirements. The most usual ones have been polypropylene bags of $50 \mathrm{~kg}$ and $25 \mathrm{~kg}$. Although there are also bigbags of $1250 \mathrm{Kg}$. Regarding the method of sale in gondolas, the packages are usually varied, but always less than $1 \mathrm{Kg}$.

Regarding the pricing strategy, it was investigated that the FOB values of comparable products were at a somewhat high level. Therefore, taking the lower limits (cost of the product) and the upper limits (competition), and since there was a good demand for the product, determined by the availability and capacity of the clients to buy, the strategy of fixing the export price was chosen. The alternative of fixing a penetration price was selected, where the product was offered at a low price, in order to generate an attractive and good level of sales to conquer a greater market share, at least until it was established in the destination country, as a recurrent seller considering it to be the most convenient option for "Maní S.A." in its nascent incursion as a direct exporter.

If we return to Table 2 of this work, we see that Chile imported in 2018, roasted peanuts from Argentina at an average value of 1,522 dollars FOB per ton. As mentioned above, the best thing for the company is to seek around 1520 dollars FCA per ton in exports, also analyzing alternatives for insurance and land or sea freight that do not raise the price of goods above that figure.

As an assumption for the exportation and knowing that the company produces around 350 tons of peanuts per year, we took the value of five terrestrial trucks with 20 net tons each one, dividing the merchandise in 16 "big-bags" of $1250 \mathrm{Kg}$. By regulation of national law Argentina, the trucks are insured to move freely without inconvenience.

With regard to Chile's internal taxes, the VAT to be paid is $19 \%$, which is collected at the Customs of the country of destination. The importation of food products or sub-products of animal or vegetable origin requires the intervention of the "Servicio Agrícola y Ganadero" (SAG). The Certificate of Food Destination (CDA), which allows the food to be removed from the customs area, has a minimum tariff of USD 27.50 and a maximum of USD 137, depending on the kilos of product. The "SAG" charges a fixed amount of USD 65 for the customs destination, regardless of the quantity.

In order to form a "DDP" price, the "CIP" value is subject to the customs tariff, which is generally $6 \%$, but thanks to the AAP.CE $\mathrm{N}^{\circ} 35$ agreement, for Argentina the tariff is $0 \%$. The CIP value is then added to the customs duties and 19\% VAT is applied. Other taxes and expenses are added if SAG or CDA certificates are required. Table 10 below provides information on quotations and the different values.

Table10. Quote details 5 trucks of 20 tons each.

\begin{tabular}{|c|c|c|c|c|}
\hline Quote details & Currency & Quantity & Unitary & Sub Total \\
\hline VALUE FCA & USD & 5 & 30400,00 & 152000,00 \\
\hline Entrance to CaCEC and Consolidation & USD & 5 & 220,00 & 1100,00 \\
\hline Cordillera Border - Customs & USD & 5 & 55,00 & 275,00 \\
\hline Land freight & USD & 5 & 1920,00 & 9600,00 \\
\hline Issuance of CRT + MIC-DTA & USD & 5 & 75,00 & 375,00 \\
\hline Cargo insurance & USD & $0,45 \%$ & 136,80 & 684,00 \\
\hline VALUE CIP & USD & 5 & 32806,80 & 164034,00 \\
\hline IVA & USD & 5 & 6233,29 & 31166,46 \\
\hline SAG & USD & 5 & 65,00 & 325,00 \\
\hline CDA & USD & 5 & 137,00 & 685,00 \\
\hline Expenditure in Land Port "Los Andes" & USD & 5 & 410,00 & 2050,00 \\
\hline Customs clearance costs & USD & 5 & 85,00 & 425,00 \\
\hline VALUE DDP & USD & 5 & 39737,09 & 198685,50 \\
\hline
\end{tabular}

Source: Own elaboration based on freight agent data 
As a strategy of market or distribution it was proposed to make a direct export, with a direct distribution channel to a Chilean distributor, since they are the first exports of the firm, and in which the quantities are not extremely large. It can also be mentioned that the local representative, has more knowledge about the market, which facilitates its sale and distribution. It would not be possible to talk about installing franchises or points of sale in Chile without first having a good knowledge of the market and having had experience in it; furthermore, it requires an extremely large investment that the company is not in a position to finance at the moment.

\section{CONCLUSION AND RECOMMENDATIONS}

As Argentina has a great reputation worldwide in peanuts and added to the different organizations that promote the quality and expansion of this product, it is estimated that "Maní S.A." has potential for both its own production of roasted peanuts and for export. However, it is essential to have an international trade department, created with the participation of professionals trained in international trade. Likewise, the company must register as an importer for the purchase of inputs necessary for its operation and as an exporter to take its products directly to its customers abroad. Also between the dilemma of outsourcing or investing in machinery for drying and processing of roasted peanuts, it was estimated that to be more competitive in operating costs of the entire production process and export, it is necessary to internalize the entire production process.

The most convenient thing for the company, not having experience in export, was to look for destinations of easy and quick access, as far as possible close geographically and in the same language. Countries that had these variables were analyzed and it was concluded that the Chilean market is the most beneficial for the introduction of roasted peanuts, since the market already exists, with a good price, growing consumption trends and is not saturated. Based on the investigation and the lack of experience of the company, it is considered convenient to start with an export of approximately 110 tons of roasted peanuts, packed in 70 "big-bags" of polypropylene of 1250 kilograms. Due to its logistic costs, the cargo is transported in five trucks. It is also crucial to take advantage of the opportunities offered by international fairs, which is key for exporters to make their products known and to access new commercial alternatives.

\section{REFERENCES}

[1] Ackermann, B. (2006). "Maní Argentino: Oportunidades y desafíos" XXI Jornada Nacional de Maní, Centro de Ingenieros Agrónomos (CIA) INTA, p.48-50.

[2] Aguilar, F. (1967). Análisis del entorno empresarial.

[3] Akhtar, S., Khalid, N., Ahmed, I., Shahzad, A. \& Suleria, H. (2014). Physicochemical Characteristics, Functional Properties, and Nutritional Benefits of Peanut Oil: A Review. Critical Reviews in Food Science and Nutrition, 54, 1562-1575.

[4] Akgün, A., Keskin, H. \& Ayar, H. (2014). Standardization and Adaptation of International Marketing Mix Activities: A Case Study. Procedia - Social and Behavioral Sciences, 150, 609-618.

[5] Ámbito. (2020). Ambito.com. Obtenido de https://www.ambito.com/la-balanza-comercial-registro-suundecimo-superavit-consecutivo-llego-us951-millones-julio-n5049966

[6] Banco Mundial. (2020). Banco Mundial. Obtenido de http://www.bancomundial.org

[7] BCR. (2020). Bolsa de Comercio de Rosario. https://www.bcr.com.ar/es/mercados/investigacion-ydesarrollo/informativo-semanal/noticias-informativo-semanal/argentina-8

[8] BCRA. (2020). Banco Central de la Republica Argentina. https://www.bcra.gob.ar/Publicaciones Estadisticas/Evolucion_moneda_2.asp

[9] Bibbo, M., Fantuzzi, Vicentin, C. \& Monguillot, J. (2018). Análisis de caso del cluster manisero para la producción de granos de maní con bajos insumos químicos. Facultad de Ciencias Agropecuarias. Universidad Nacional de Córdoba. Argentina. https://rdu.unc.edu.ar/bitstream/handle/11086/11287/ Bibbo\%3B\%20Fantuzzi\%20Vicentini\%3B\%20Monguillot\%20\%20An\%C3\%A1lisis\%20de\%20caso\%20d el\%20cluster\%20manisero\%20para\%20la\%20producci\%C3\%B3n\%20de\%20granos\%20de\%20man\%C3 $\% \mathrm{AD} \% 20 \mathrm{con} \% 20 \mathrm{bajos} \% 20$ insumos\%20qu\%C3\%ADmicos.pdf?sequence=1\&isAllowed=y

[10] Bonku, R. \& Yu, J. (2020). Health aspects of peanuts as an outcome of its chemical composition. Food Science and Human Wellness, 9, 21-30.

[11] Calzada, J. \& Rozadilla, B. (2018). Argentina líder en exportaciones del complejo maní. Bolsa de cereales de Rosario. https://www.bcr.com.ar/Pages/Publicaciones/informativosemanal_noticias.aspx?pIdNoticia $=1303$ 
[12] Cámara Argentina del Maní (CAM). (2014). Informe de estadísticas de producción. http://www. camaradelmani.org.ar/espanol/tag/informe-produccion-mani/

[13] Cámara Argentina del Maní (CAM). (2017). El cluster manisero argentino. http://www.cámaradelmani. org.ar/espanol/outlook/

[14] CAM. (2020). Camara Argentina del Maní. http://www.camaradelmani.org.ar/espanol/cluster-maniseroargentino/

[15] Cateora, P. (1995). Marketing Internacional. Madrid: S.A. Elsevier, España.

[16] Dichev, I. (2020). Fifty years of capital markets research in accounting: Achievements so far and opportunities ahead. China Journal of Accounting Research (in press).

[17] Di Stasio, L., Tranquet, O., Picariello, G., Ferranti, P. Morisset, M., Denery-Papini, S. \& Mamone, G. (2020). Comparative analysis of eliciting capacity of raw and roasted peanuts: the role of gastrointestinal digestion. Food Research International, 127, 108758.

[18] El Cronista. (2020). El Cronista. https://www.cronista.com/economiapolitica/Argentina-firmo-20acuerdos-de-libre-comercio-desde-1990-mejoran-la-balanza-comercial-20190706-0009.html

[19] Exportadores de Córdoba. (2020). https://www.exportadoresdecordoba.com/listado-productos.asp?desc= \&posar $=2008.11 .00 \& \mathrm{sec}=\&$ rubro $=$

[20] Falahat, M., Ramayah, T., Soto-Acosta, P. \&Lee, Y-Y. (2020). SMEs internationalization: The role of product innovation, market intelligence, pricing and marketing communication capabilities as drivers of SMEs' international performance. Technological Forecasting and Social Change, 152, 119908.

[21] Fundación Maní Argentino. (2020). Fundación Maní Argentino. Obtenido de http://fundacionmani.org.ar/

[22] Guo, C., Xie, Y-J., Zhu, M-T., Xiong, Q., Chen, Y., Yu, Q. \& Xie, J-H. (2020). Influence of different cooking methods on the nutritional and potentially harmful components of peanuts. Food Chemistry, 316, 126269.

[23] International Trade Center. (2020).https://bit.ly/2BOEycH

[24] Hair, J., Bush, R., \& Ortinau, D. (2010). Investigación de Mercados en un ambiente de informacion digital. Mexico D.F.: McGraw Hill.

[25] Illa, C., Olivo, A., Gamba, J., Sebastián y Pérez, M., Trossero, D., \& Pérez, M. A. (2017). Producción de maní en la zona centro-norte de Córdoba: evaluación de la respuesta a la aplicación de tratamiento combinado de fungicida más inoculante en semillas versus tratamiento en surco. En: XXXII Jornada Nacional de Maní. General Cabrera, Córdoba. http://www.ciacabrera.com.ar/docs/JORNADA\%2032/32Illa,\%20C.\%201.docx.pdf;\%20Olivo,\%20A.\%201.docx.pdf;\%20Gamba,\%20J.\%202.docx.pdf;\%20Sebasti \%C3\%A1n\%20y\%20P\%C3\%A9rez,\%20M.\%201.docx.pdf;\%20Trossero,\%20D.3.docx.pdf;\%20P\%C3\% A9rez,\%20M.A.\%201.pdf

[26] INDEC. (2020). INDEC. https://www.indec.gob.ar/indec/web/Nivel4-Tema-3-5-31Instituto Nacional de Comercio Exterior y Aduanas. (2020). Instituto Nacional de Comercio Exterior y Aduanas. Obtenido de http://www.comercioyaduanas.com.mx/

[27] Jovits, M. y Juez, C. (2014). Área de Consolidación Gestión de la Producción de Agroalimentos. Análisis del cluster manisero: importancia de la calidad del insumo semilla. Facultad de Ciencias Agropecuarias. Universidad Nacional de Córdoba. https://rdu.unc.edu.ar/bitstream/handle/11086/1568/Jovtis\%20$\% 20 \mathrm{Juez} \% 20 \mathrm{An} \% \mathrm{C} 3 \%$ A1lisis $\% 20 \mathrm{del} \% 20$ cluster\%20manisero.pdf?sequence=4\&isAllowed=y

[28] Keegan, W. (2000). Marketing Global. Prentice Hall.

[29] Kong, F., Oztop, M., Singh, R. \& McCarthy, M. (2013). Effect of boiling, roasting and frying on disintegration of peanuts in simulated gastric environment. LWT - Food Science and Technology, 50: 1, 32-38.

[30] Kotler, P. \& Keller, K. L. (2017). Dirección de Marketing. México: Pearson.

[31] Launio, Ch., Luis, J. \&Angeles, Y. (2018). Factors influencing adoption of selected peanut protection and production technologies in Northern Luzon, Philippines. Technology in Society, 55, 56-62.

[32] Ministerio de Agricultura, Ganadería y Pesca (MAGyP). http://www.alimentosargentinos.gob.ar/Home Alimentos/Cadenas\%20de\%20Valor\%20de\%20Alimentos\%20y\%20Bebidas/informes/MANI_Resumen_1 er_sem_2019.pdf

[33] Ministerio de Agroindustria de la Argentina-(MAGyP). https://www.magyp.gob.ar/sitio/areas/ss_mercado s_agropecuarios/apertura_de_mercados/analisis_foda/_archivos/000506_Man\%C3\%AD\%20\%202018.pdf

[34] Ministerio de Ciencia, Tecnología e Innovación Productiva (MCTeIP). (2020). Ministerio de Ciencia, Tecnología e Innovación Productiva. Obtenido de https://www.argentina.gob.ar/ciencia

[35] Ministerio de Relaciones Exteriores y Culto (MREyC. (2020). Gestionando la inserción internacional: inventario de barreras a las exportaciones argentinas 2018.1 a edición. Ciudad Autónoma de Buenos Aires. 
[36] Mitch, L. (2019). Maní, en Córdoba está la producción más dulce del mundo. El abc Rural. https://elabcrural.com/mani-en-cordoba-esta-la-produccion-mas-dulce-del-mundo/

[37] Pedelini, R. (2014). Maní: Guía Práctica para su cultivo (INTA General Cabrera) Boletín de divulgación técnica No2. INTA, Argentina.

[38] Revista Chacra (2019). https://www.revistachacra.com.ar/nota/29406-argentina-el-quinto-exportadormundial-de-mani/

[39] Riesener, M., Dolle, Ch., Schuh, G. \& Tonnes, Ch. (2019). A new methodology to analyze the functional and physical architecture of existing products for an assembly oriented product family identity. Procedia CIRP, 83, 304-310.

[40] Saaty, T. (1988). The analytical hierarchy process. Mc. Graw Hill.

[41] SantanderTrade. (2020). SantaderTrade. Obtenido de https://es.portal.santandertrade.com/?\&actualiser _id_banque=oui\&id_banque $=3 \&$ memoriser_choix $=$ memoriser

[42] Shi, A., Wang, Q., Liu, H., Wang, L., Zhang, J., Du, J. \& Chen, X. (2016). Peanut Processing Quality Evaluation Technology. Peanuts: Processing Technology and Product Development, Chapter 2, 23-61.

[43] Shi, X., Davis, J., Xia, Z., Sandeep, K.P., Sanders, T. \& Dean, L. (2017). Characterization of peanuts after dry roasting, oil roasting, and blister frying. LWT, 75, 520-528.

[44] TARIFAR. (2020). Tarifar. http://www.tarifar.com.ar

[45] The Heritage Foundation. (2020). 2020 Index of Economic Freedom. https://www.heritage.org/index/

[46] Tarka, P. (2019). Managers' cognitive capabilities and perception of market research usefulness. Information Processing \& Management, 56: 3, 541-553.

[47] Trade Map. (2020). International Trade Center. https://www.trademap.org/Index.aspx

[48] Universidad Siglo 21. (2020). Canvas Universidad Siglo 21. http://www.siglo21instructure.com

[49] Zapata, N., Vargas, M. \& Vera, F. (2012). Crecimiento y productividad de dos genotipos de maní (Arachis hypogaea L.) según densidad poblacional establecidos en Ñuble, Chile. IDESIA, 30:3, 47-54.

[50] https://www.peanutsusa.com/about-apc/the-peanut-industry.html

[51] https://www.tridge.com/intelligences/peanut/production

\section{AUTHORS' BIOGRAPHY}

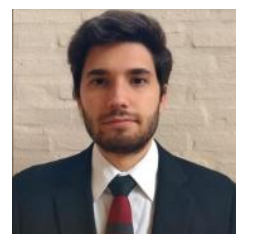

"He obtained his Bachelor's Degree in International Trade at the Universidad Siglo 21, Córdoba, Argentina in 2020. He is currently a candidate for a Master's degree in Industrial Engineering at the Polytechnique of Montreal, Canada, in the area of logistics. He is currently working as a co-researcher on issues of foresight, technological logistics and international trade in Chile and Argentina".

Citation: Tomas Agustín BAS. "Logistical Market Opportunities for Roasted Peanut Exports. A Case Study" International Journal of Managerial Studies and Research (IJMSR), vol 8, no. 10, 2020, pp. 48-62. doi: https://doi.org/10.20431/2349-0349.0810006.

Copyright: (C) 2020 Authors. This is an open-access article distributed under the terms of the Creative Commons Attribution License, which permits unrestricted use, distribution, and reproduction in any medium, provided the original author and source are credited. 